\title{
Dynamics of a temperature-related coral disease outbreak
}

\author{
Ross J. Jones ${ }^{1, *}$, Jocelyn Bowyer ${ }^{2}$, Ove Hoegh-Guldberg ${ }^{3}$, Linda L. Blackall ${ }^{2}$ \\ ${ }^{1}$ Bermuda Biological Station for Research, St George's GE01, Bermuda \\ ${ }^{2}$ School of Molecular and Microbial Sciences, The University of Queensland, Brisbane, Queensland 4072, Australia \\ ${ }^{3}$ Centre for Marine Studies, The University of Queensland, Brisbane, Queensland 4072, Australia
}

\begin{abstract}
During the austral summer of 2001/2002, a coral epizootic occurred almost simultaneously with a bleaching event on the fringing reefs of Magnetic Island (Great Barrier Reef region), Australia. This resulted in a 3- to 4 -fold increase in the mean percentage of partial mortality rate in a population of the hard coral Montipora aequituberculata. The putative disease state, 'atramentous necrosis', was observed on both bleached and normally-pigmented $M$. aequituberculata, and presented blackened lesions that spread within days across the colony surface and throughout the population. Diseased portions of the corals were only visible for 3 to $4 \mathrm{wk}$, with diseased tissues becoming covered in sediment and algae, which rapidly obscured evidence of the outbreak. Diseased colonies were again observed in the summer of 2002/2003 after being absent over the 2002 winter. Analysis of when diseased and bleached corals were first observed, and when and where the mortality occurred on individual colonies, indicated virtually all the mortality over the summer could be attributed to the disease and not to the bleaching. Fluorescence in situ hybridisation (FISH) techniques and cloning, and analysis of the 16S rRNA genes from diseased coral tissue, identified a mixed microbial assemblage in the diseased tissues particularly within the Alphaproteobacteria, Firmicutes and Bacteroidetes. While it is not possible in this study to distinguish between a disease-causing microbial community versus secondary invaders, the bacterial $16 \mathrm{~S}$ rDNA sequences identified within the blackened lesions demonstrated high similarity to sequences from black band disease and white plague infected corals, suggesting either common aetiological agents or development of a bacterial community that is specific to degrading coral tissues. Temperature-induced coral disease outbreaks, with the potential for elevated levels of mortality, may represent an added problem for corals during the warmer summer months and an added dimension to predicted increases in water temperature from climate change.
\end{abstract}

KEY WORDS: Coral bleaching $\cdot$ Black band disease $\cdot$ Atramentous necrosis $\cdot$ Great Barrier Reef

\section{INTRODUCTION}

Recently, there has been a worldwide increase in the reports of diseases affecting marine organisms, including sponges, seagrasses, sea urchins, shellfish, fish, marine mammals and corals (Harvell et al. 2002). Diseases have the potential to cause marked population declines, threaten biodiversity, and by threatening susceptible species, result in a change in community structure. A classic example of the latter is a phase-shift from coral- to algal-dominated reefs in the Caribbean following the loss of the sea-urchin Diadema antillarum to an unknown pathogen (Hughes 1994). Other examples include the progressive elimination of Acropora cervicornis and A. palmata in the Caribbean by white band disease (Aronson et al. 1998), and A. palmata in the Florida Keys by white pox (Patterson et al. 2002). The dynamics of intermittent, ephemeral, threshold phenomena such as disease outbreaks are poorly understood (Harvell et al. 2002), especially with respect to scleractinian corals. 
Currently, there are nearly 30 proposed names for coral diseases, although most have not been properly classified and many may refer to the same or similar disease. The status of the new diseases are confused (Richardson 1998). The better described diseases of scleractinian corals include black band disease (Antonius 1973), white band disease (Gladfelter et al. 1977), white band disease Type II (Ritchie \& Smith 1998), white plague (Dustan 1977), white plague Type II (Zorpette 1995), white pox (Patterson et al. 2002) and yellow blotch disease (Reeves 1994). Koch's postulates have only been satisfied in a few of these diseases (see Richardson 1998).

Several recent reviews speculate that there has been an increase in the reports of coral disease in the 1990s (Santavy \& Peters 1997, Goreau et al. 1998, Hayes \& Goreau 1998, Richardson 1998). There is direct evidence of a recent increase in the number of reefs in the Florida Keys where disease is present, and an increase in the number of coral species that are affected (Porter et al. 2001). What has caused this increase is unknown. The prevalence of disease in the wider Caribbean area (see also Peters 1997), and a correlation (albeit on a regional rather than local scale) between the distribution of outbreaks and threats to reefs by anthropogenic factors has been noted (Green \& Bruckner 2000). In addition to human activities, warming trends, coupled with extreme El Niño Southern Oscillation events, might be contributing to the emergence of new marine disease (Harvell et al. 2002, Rosenberg \& Ben-Haim 2002). In marine and terrestrial systems, increased temperature can increase pathogen development, transmission and growth rates, and decrease host resistance. This can directly affect the abundance and geographic range of pathogens (Harvell et al. 2001). Irrespective of the cause, the patterns observed in coral disease in the last decade may indicate a decline in the condition of coral reefs. Coral disease may have the potential to act as a bioindicator of reef health, or even marine health in general (Harvell et al. 1999, Green \& Bruckner 2000).

For scleractinian corals, understanding links between temperature and disease are complicated by the phenomenon of coral bleaching, the dissociation of the coral-algal symbiosis under conditions of unusually warm seawater temperature (Glynn 1996, Brown 1997, Hoegh-Guldberg 1999, Douglas 2003). Mass coral bleaching is a physiological stress response resulting from the impairment of algal photosynthesis at elevated water temperatures (HoeghGuldberg 1999, Fitt et al. 2001), although some studies have suggested that bleaching is caused by bacterial infection (recently reviewed by Douglas 2003). Mortality associated with coral bleaching events varies between species (Loya et al. 2001), increasing with the intensity and length of the stress. In some instances, the mortality associated with mass coral bleaching can be quite extensive (Loya et al. 2001). Whether the mortalities associated with bleaching events are the result of the bleachingstress itself, or of opportunistic disease infection postbleaching has recently been questioned. Mortality in gorgonians Briareum asbestinum during a bleaching event in the Florida Keys has been attributed to a disease rather than the bleaching stress itself (Harvell et al. 2001).

Understanding the relationship between coral disease, coral bleaching and coral mortality has been difficult because of a lack of insight into many of the fundamental processes associated with coral disease. Marine microbial systems associated with coral reefs are very poorly characterised (Ritchie et al. 2001), and traditional culturing techniques are largely ineffective and highly selective with environmental samples (Amann et al. 1995). Recently, significant progress has been made with the application of modern molecular and microbiological techniques, including sequencing of conserved regions of the microorganism's genome (frequently genes encoding the small subunit RNAs, 16S rRNA or 18S rRNA), and use of fluorescence in situ hybridization (FISH). These 'culture-independent' techniques have the potential to provide a more comprehensive and precise picture of microorganisms associated with a disease, and have already been used effectively to provide analyses of both diseased and healthy coral tissues (Rohwer et al. 2001, Bythell et al. 2002, Cooney et al. 2002, FriasLopez et al. 2002).

The relationship between coral disease, coral bleaching and coral mortality has also been difficult to decipher due to the ephemeral nature of bleaching events and disease epizootics. Few studies have been able to quantify the prevalence of diseased corals and/or bleached corals, or followed the associated mortality over time (Bruckner 2002). In this study, we describe a dramatic example of a coral disease epizootic co-occurring with a coral bleaching event on the inshore Great Barrier Reef. We describe the epizootiology (the prevalence and variability at local, regional and temporal scales, factors involved in the occurrence and spread, and the effect on host populations: Bruckner 2002) of the disease outbreak and quantify the rapid decimation of one of the species involved. We demonstrate that the mortality was almost exclusively caused by the disease and did not result from the bleaching. Results of a preliminary investigation of the potential pathogens involved in the disease using FISH and molecular screening techniques of $16 \mathrm{~S}$ rRNA genes are also presented. 


\section{MATERIALS AND METHODS}

In situ studies. Magnetic Island $\left(19^{\circ} \mathrm{S}, 147^{\circ} \mathrm{W}\right)$ is a continental island situated approximately $8 \mathrm{~km}$ north of the mainland city of Townsville, Australia (Fig. 1). Fringing reefs occur on the SE side of the island as assemblages of coral and algae overlying platforms of accumulated non-biogenic sediments. Five study sites were established at Bright Point and 2 each at Arthur Bay and Florence Bay. At each site, 25 to 80 colonies of Montipora aequituberculata located at 4 to $6 \mathrm{~m}$ depth on the reef slope were marked with numbered plastic tags. All colonies were photographed and the photographs laminated to allow use underwater. On the laminated photograph, any areas of the colony that were dead or discoloured were marked with indelible ink and the percentage of the colony bleached or dead was quantified. At approximately 6 wk intervals, a subset (15 to 25) of the available corals at each site was examined and any change in the areas considered dead or bleached was marked on the laminated photographs underwater with china graph pens. The percentage of the colony that was bleached or dead was then re-quantified. To accommodate for growth of the corals over the project, all corals were re-photographed every $24 \mathrm{wk}$ and the percentage bleaching and percentage partial mortality re-quantified on the new photographs.

At approximately weekly intervals, visual assessments were made of all corals at Bright Point and any corals that were more than $10 \%$ bleached or had greater than $5 \%$ partial mortality recorded. Corals were also allocated into the following categories: (1) normally pigmented (i.e. possessing a typical brown colouration with a paler growing margin (edge) not contributing to $>10 \%$ of the surface area of the coral, (2) partially bleached, (3) fully bleached (i.e. $>95 \%$ of the surface area of the colony was white) or (4) dead. The 'partially bleached' category included all living colonies that had uniformly discoloured patches (but not enough to warrant inclusion in Category 3) and corals with fully bleached patches, but which also retained areas of slightly discoloured or even normally pigmented tissue (i.e. colonies that displayed a variegated or 'mottled' pattern of bleaching). In addition, the presence or absence of excessive mucus production and any incidence of coral disease was recorded.

A bleaching event occurred at Bright Point in early January 2002. On 31 January 2002, surveys were conducted at Bright Point and Florence Bay, and all tagged colonies $(n=206)$ were examined for bleaching, mortality and the presence of disease. All corals were assigned to the 4 categories described previously and the total surface area of the colony covered by any disease was estimated visually (to within $10 \%$ ). From this analysis, corals could be placed into a further 4 categories: (1) not bleached and not diseased (i.e. healthy), (2) not bleached but diseased, (3) not diseased but bleached, (4) bleached and diseased.

Seawater temperatures $\left({ }^{\circ} \mathrm{C}\right)$ at 5 to $6 \mathrm{~m}$ depth were recorded at $0.5 \mathrm{~h}$ intervals at Bright Point and Florence Bay using waterproof platinum RTD thermocouple sensors (data obtained from the Great Barrier Reef Marine Park Authority, GBRMPA, Seawater Temperature Monitoring Program), and at Arthur Bay using Optic Stowaway ${ }^{\circledR}$ temperature loggers (Onset Computer Corporation).

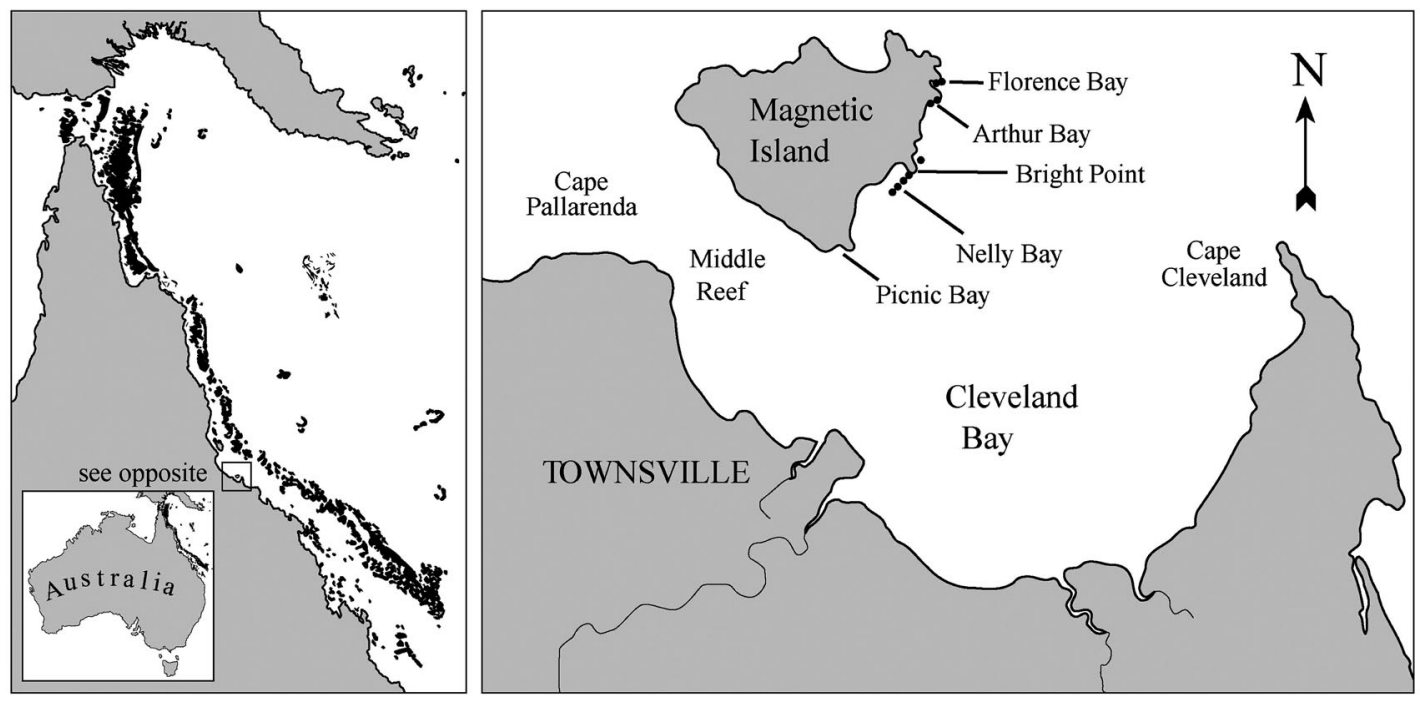

Fig. 1. Magnetic Island, situated $8 \mathrm{~km}$ north of the mainland city of Townsville. Study sites $(\mathrm{n}=5)$ were located at Bright Point and Geoffrey Bay, adjacent to Bright Point and Florence Bay $(n=2$ sites) and Arthur Bay $(n=2$ sites). Seawater temperature loggers were located within Arthur Bay, Florence Bay and at the southern section of Nelly Bay 
Microbial analyses. On 7 February 2002, 5 diseased colonies of Montipora aequituberculata were collected from 5 to $6 \mathrm{~m}$ depth at Nelly and Geoffrey Bay for microbiological analysis. A selection of coral tissue types were sampled that covered both diseased regions and unaffected coral tissue (see subsection below), including (1) normally-pigmented coral tissue, (2) blackened tissue and (3) a white surface layer overlying the blackened tissues. Sediments around the corals were also sampled.

Fixation of coral samples was done in $4 \%$ paraformaldehyde (Amann et al. 1990). Commercially synthesised oligonucleotide probes were 5 '-labelled with one of the sulfoindocyanine dyes Cy3 or Cy5 (Thermohybaid Interactiva). Fixed samples were dual hybridised with the bacterial probe EUBMIX, labelled with Cy5, and a group probe labelled with Cy3 (see Table 1). FISH hybridisation was carried out and observed as previously reported (Björnsson et al. 2002). Total DNA was extracted from one coral specimen from Geoffrey Bay using the bead beating procedure (FastDNA ${ }^{\circledR}$ Spin Kit BIO 101). This specimen displayed both white and black areas affected by the coral disease. A bacterial 16S rRNA gene (16S rDNA) clone library was prepared from the genomic DNA using the universal bacterial primer set $27 \mathrm{f}$ and 1492r (Lane 1991). Polymerase chain reaction (PCR) incorporating an initial thermal denaturation step and bacterial clone library preparation were carried out as previously described (Burrell et al. 1998). Representative clones determined from restriction fragment length polymorphism (RFLP) analysis were partially DNA sequenced using primer 907r (Lane 1991). Prior to DNA sequencing, the $16 \mathrm{~S}$ rDNA PCR product of representative clones was purified using QIAquick ${ }^{\circledR}$ purification kit (Qiagen). DNA sequencing used a Big Dye Terminator Version 3 sequencing kit. Reactions were analysed at the Australian Genome Research Facility (Brisbane, Australia). Sequences were compiled using the software package SeqEd Version 1.0.3 (Applied Biosystems). Each partial 16S rDNA sequence was compared to sequences available in GenBank using the basic local alignment search tool (BLAST; Altschul et al. 1990) to determine the closest sequence matches. The compiled sequences and 10 of their closest matches highlighted from BLAST were aligned using the ARB software package and database (www.arbhome.de) and alignments were refined manually. Phylogenetic trees were constructed by carrying out evolutionary distance analysis on the 16S rDNA alignments, using the appropriate tool in the ARB database (Björnsson et al. 2002). Clone 16S rDNA insert sequences obtained in this study were deposited in GenBank under the accession numbers AY348720AY348738 and AY348859-AY348862.

\section{RESULTS}

\section{In situ studies}

At Bright Point, there were 2 pronounced peaks in seawater temperature over the summer, the first in early January 2002 and the second in early February 2002. In the first peak, maximum daily seawater temperatures exceeded $31.5^{\circ} \mathrm{C}$ for $15 \mathrm{~d}$ and in the second peak for $10 \mathrm{~d}$ (Fig. 2). Over these periods, the average daily seawater temperatures varied by 1 to $2^{\circ} \mathrm{C}$. Average seawater temperatures for the peak summer months were: December $2001,30.3^{\circ} \mathrm{C}_{i}$ January 2002 , $30.8^{\circ} \mathrm{C}$; February, $30.8^{\circ} \mathrm{C}$. Seawater temperatures at Bright Point in the summer of $2002 / 2003$ were $\sim 2^{\circ} \mathrm{C}$ cooler than in 2001/2002.

At Florence Bay, there was a minor peak in seawater temperature in January 2002 (maximum $31.3^{\circ} \mathrm{C}$ ) and a clear peak occurred in early February, in which the maximum daily seawater temperatures exceeded $31.5^{\circ} \mathrm{C}$ for $3 \mathrm{~d}$. The average daily seawater tempera-

Table 1. Fluorescence in situ hybridization (FISH) oligonucleotide probes used to examine the diseased Montipora aequituberculata tissues. Microorganisms in samples of $M$. aequituberculata, where: +: present, - : absent, \pm : present in some samples but not in all. Symbiotic dinoflagellates were present in all samples excepting the sediments. Norm: normal tissue (3), DW: diseased

tissue white (5), DB: diseased tissue black (1), DG: diseased tissue grey (1), Sed: sediment (1); no. of samples in brackets

\begin{tabular}{|c|c|c|c|c|c|c|c|c|c|}
\hline FISH & Target & rRNA target & E. coli no. & Norm & DW & DB & DG & Sed & Source \\
\hline EUBMIX & All Bacteria & $16 \mathrm{~S}$ & $338-$ & - & + & + & + & + & $\begin{array}{l}\text { Amann et al. (1990), } \\
\text { Daims et al. (1999) }\end{array}$ \\
\hline ALF1b & Alphaproteobacteria & $16 \mathrm{~S}$ & $19-35$ & - & + & + & + & + & Manz et al. (1992) \\
\hline BET42a & Betaproteobacteria & $23 \mathrm{~S}$ & $1027-1043$ & - & \pm & - & - & + & Manz et al. (1992) \\
\hline GAM42a & Gammaproteobacteria & $23 \mathrm{~S}$ & $1027-1043$ & - & \pm & + & - & - & Manz et al. (1992) \\
\hline CF319a & $\begin{array}{l}\text { Cytophaga-Flavobacterium } \\
\text { of Bacteroidetes }\end{array}$ & $16 \mathrm{~S}$ & $319-336$ & - & \pm & - & + & + & Manz et al. (1996) \\
\hline SRB683 & $\begin{array}{l}\text { Desulfovibrio in Deltaproteo- } \\
\text { bacteria }\end{array}$ & $16 \mathrm{~S}$ & $683-703$ & - & + & - & - & + & Devereux et al. (1992) \\
\hline
\end{tabular}


(a)

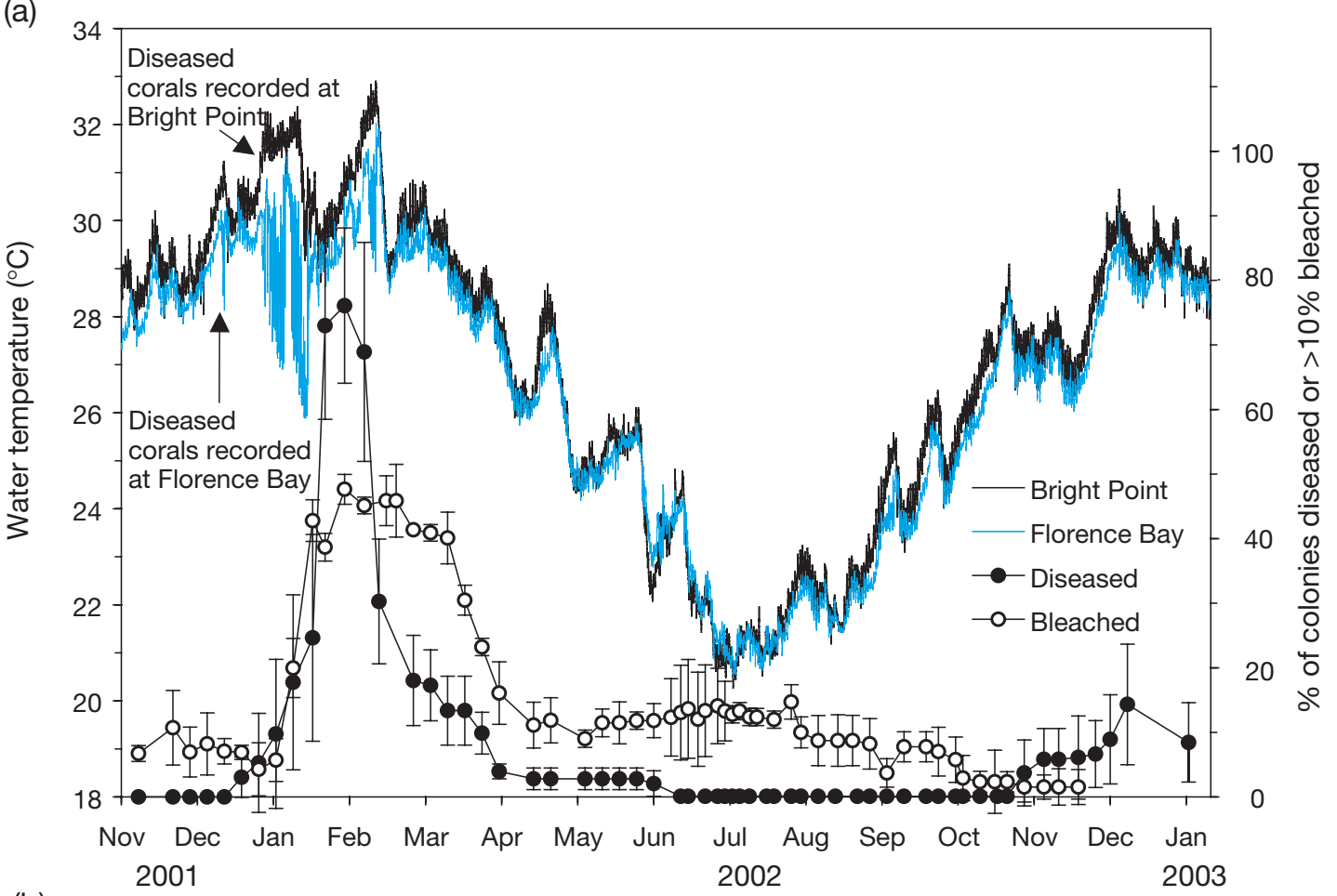

(b)

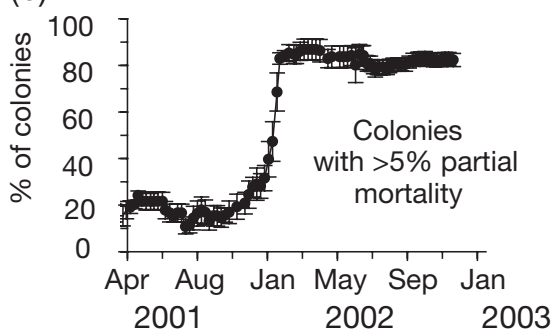

Fig. 2. (a) Primary $y$-axis: water temperature $\left({ }^{\circ} \mathrm{C}\right)$ at 5 to $6 \mathrm{~m}$ depth (below MLWS) at Bright Point or Florence Bay from November 2001 until January 2003. Secondary $y$-axis: Montipora aequituberculata mean percentage of colonies at Bright Point with diseased lesions $(\bullet)$, or $>10 \%$ bleached (O). (b) mean percentage of colonies at Bright Point with $>5 \%$ partial mortality. All percentage data are $\overrightarrow{<->} \pm \mathrm{SE}, \mathrm{N}$ $=5$ sites $(\mathrm{n}=153$ colonies total $)$. Arrows indicate when diseased corals were first observed at Bright Point and Florence Bay

ture range at Florence Bay was unusual over the summer period, exceeding a $2^{\circ} \mathrm{C}$ diel range on 17 consecutive days (and on one occasion exceeding $4^{\circ} \mathrm{C}$, Fig. 2). Similar pronounced diel ranges have only once been observed before in the $10 \mathrm{yr}$ temperature record, during the summer of 1998 (R. J. Jones unpubl. data). Average seawater temperatures for the peak summer months were: December 2001, $29.5^{\circ} \mathrm{C}$; January 2002, $28.9^{\circ} \mathrm{C}$; February, $30^{\circ} \mathrm{C}$.

At Arthur Bay, seawater temperatures were intermediate between Bright Point and Florence Bay (data not shown). Maximum temperatures reached $32.3^{\circ} \mathrm{C}$ on 10 January 2002 and exceeded $31.5^{\circ} \mathrm{C}$ for 8 consecutive days in February 2002; pronounced diel temperature ranges were also observed, sometimes exceeding $3^{\circ} \mathrm{C}$. Average seawater temperatures for the peak summer months were: December $2001,29.7^{\circ} \mathrm{C}$; January $2002,30.2^{\circ} \mathrm{C}$; February, $30.5^{\circ} \mathrm{C}$.

In the early austral summer of 2001/2002, the percentage of colonies of Montipora aequituberculata at
Bright Point with $>5 \%$ partial mortality increased from $\sim 20 \%$ of the population $(\mathrm{n}=153)$ in December 2001 to $>40 \%$ of the population on 3 January 2002 (Fig. 2b). Over the next $20 \mathrm{~d}$, the number of colonies with $>5 \%$ partial mortality increased rapidly to $80 \%$ of the population. This period of rapid increase in partial mortality coincided with the appearance of a disease on the corals (see subsection below) and also coincided with pronounced bleaching of the corals. For example, on 3 January $2002,5 \%$ of the colonies were considered bleached (i.e. with $>10 \%$ of the surface area discoloured) and none were considered fully bleached (Fig. 2). A week later, $20 \%$ of the colonies were considered bleached and 10 of the 153 colonies examined were fully bleached. A further week later (18 January 2002), more than $40 \%$ of the population was bleached and 17 of the colonies was fully bleached (Fig. 2).

During surveys after the first week in December 2001 at Florence and Arthur Bays, and in late December 2001 at Bright Point, unusual lesions (pathological 

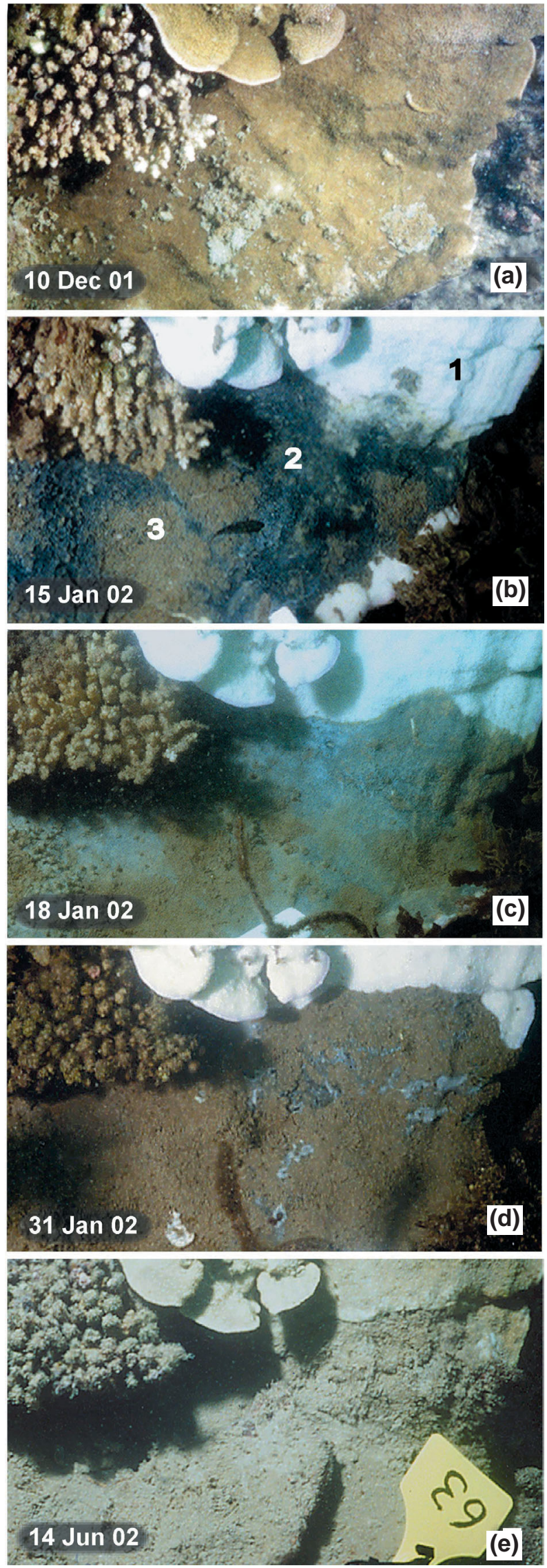

discontinuities of tissue) were noted on the colonies of Montipora aequituberculata. The lesions were usually black (atramentous), but covered in a thin light coloured film, giving the lesions a grey appearance. There was usually a sharp boundary demarcating the lesions from healthy (normally-pigmented) tissues. The lesions usually occurred in the central regions of the colonies, often appearing around hollows (indents) on the coral surface, where sediment naturally accumulates. Lesions occurred on both sunlight-exposed and shaded areas of the colony. Often colonies were located in which atramentous lesions were found on bleached tissues (Fig. 3). When first identified in December 2001, the lesions were generally small (1 to $2 \mathrm{~cm}$ across) and with a white surface film, but in January 2002 the size of the lesions began to increase, spreading outwards from central points. The superficial white film was often absent on the larger sized lesions, on bleached corals and on diseased corals towards the end of the outbreak, leading to prominent black expanses on the colonies (Fig. 3b). Outward migration of a lesion can be seen in Fig. 3b,c, where over a $3 \mathrm{~d}$ period in mid-January 2002, the growing edge of the lesion moved 4 to $5 \mathrm{~cm}$.

Between December 2001 and January 2002, the percentage of the population at Bright Point with lesions approximately doubled each week, increasing to $75 \%$ of the population ( $\mathrm{n}=153$ colonies) by the surveys of 23 January 2002 (Fig. 2). From this point onwards, there was no further increase in the number of colonies affected and no further noticeable increase in the size of the lesions. All lesions eventually became covered in sediment, turf and macroalgae, which made it progressively harder to identify which colonies had been affected (see for example Fig. 3d). Wider surveys of the reef around Bright Point in February 2002 revealed occasional fresh outbreaks; no new outbreaks were observed in March 2002. In March/April 2002, colonies started developing distinct raised lips or growing edges around the sediment-covered lesions. Diseased corals were again observed in the summer of $2002 / 2003$, although only $10 \%$ of the corals appeared affected at the height of the summer (when seawater temperatures did not

Fig. 3. Montipora aequituberculata. Development of atramentous necrosis: (a) 10 Dec 2001, normally-pigmented colony of adjacent to a small acroporid colony; (b) 15 Jan 2002, fully bleached (bone-white) tissues (1) with a prominent atramentous lesion (2), covered in a light brown layer of sediment (3); note mortality of the acroporid colony; (c) 18 Jan 2001, note the outward growth of the atramentous lesion; (d) 31 Jan 2002 , note the progressive smothering of the atramentous lesion by sediment/algae; (e) 14 June 2002, note the gradual return to normal colouration of the remaining live portion of the $M$. aequituberculata colony and the covering of the sediment covered lesion by turf algae 

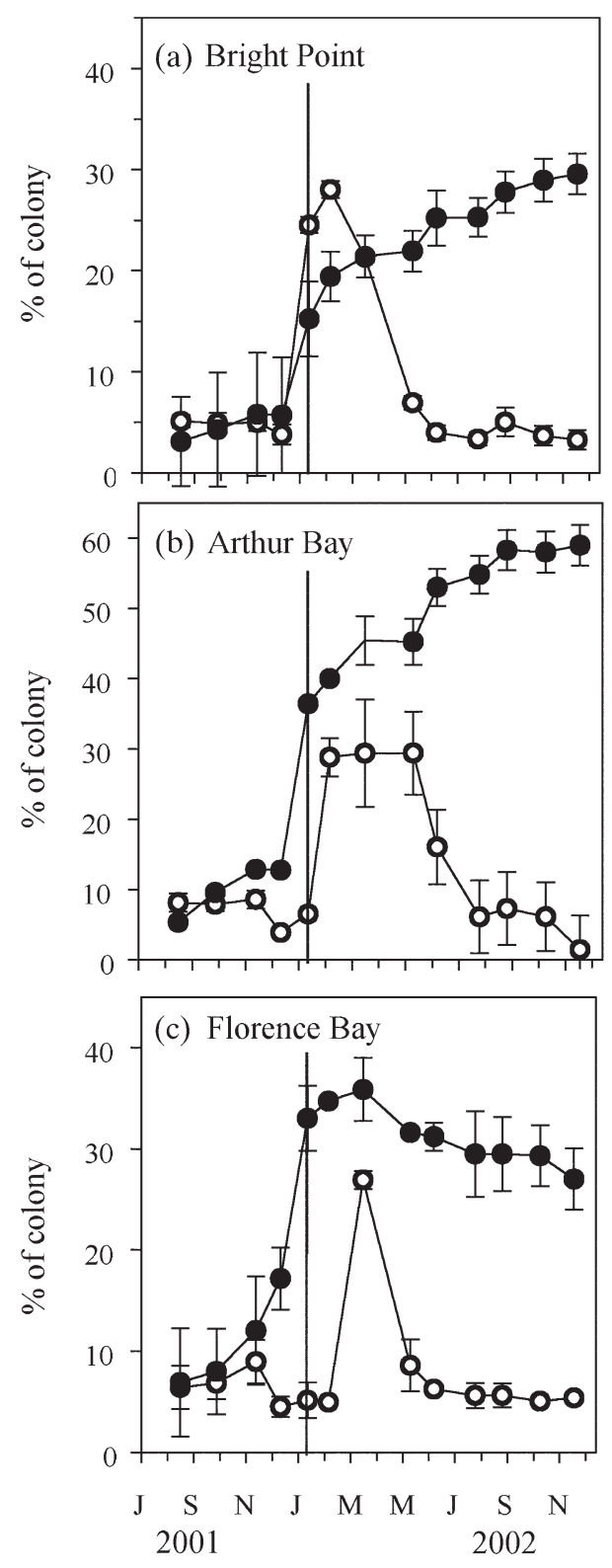

Fig. 4. Montipora aequituberculata. Mean percentage of partial mortality $(\mathbf{0})$ and percentage of partial bleaching $(\mathbf{O})$ from June 2001 to December 2002 in colonies of at (a) Bright Point (b) Arthur Bay and (c) Florence Bay. Data are $\overline{\langle->} \pm \mathrm{SE}, \mathrm{n}=95$ colonies (Bright Point) or 30 colonies (Arthur Bay and Florence Bay). Vertical line indicates surveys of 14 January 2002

exceed $31.5^{\circ} \mathrm{C}$, Fig. 2). The size of the lesions was also typically small ( 1 to $2 \mathrm{~cm}$ across) and in all cases occurred as atramentous tissues covered in a white film.

The degree of partial mortality and bleaching in Montipora aequituberculata was also assessed at $6 \mathrm{wk}$ intervals over the summer using the laminated photographs of the corals. At Bright Point, mean percent- age of partial mortality in $M$. aequituberculata increased rapidly between the sampling dates of 27 December 2001 and 14 January 2002 (Fig. 4a). Over the same period, there was a marked increase in the number of corals that appeared bleached. At Arthur Bay and Florence Bay, there was also a marked increase in partial mortality (from $\sim 10$ to $\sim 35 \%$ ) between surveys of late December and 14 January 2003. However, an increase in the percentage of corals that were bleached was only recorded during the surveys on 8 February 2002 at Arthur Bay and on 21 March 2002 at Florence Bay (Fig. 4b,c). The mean percentage of partial bleaching at all locations decreased in the late summer as corals either regained their colouration or died. By mid 2002, only a few partially bleached colonies could be found at either location. Overall, only 6 of the 153 tagged colonies at Bright Point (4\%) suffered complete (whole colony) mortality over the summer of 2001/2002.

Since many corals at Bright Point were bleached in early February 2002, but none were bleached at Flo-

(a) Bright Point

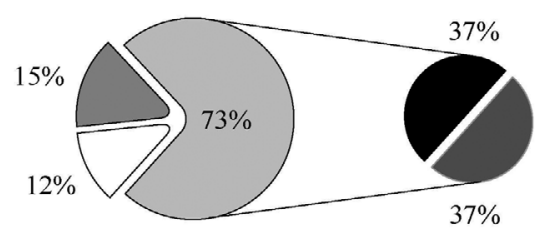

(b) Arthur Bay

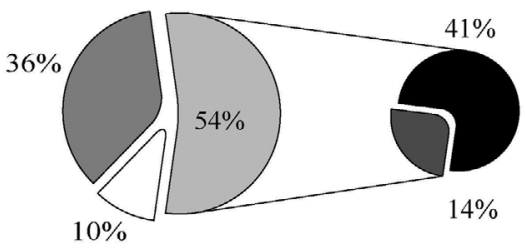

(c) Florence Bay
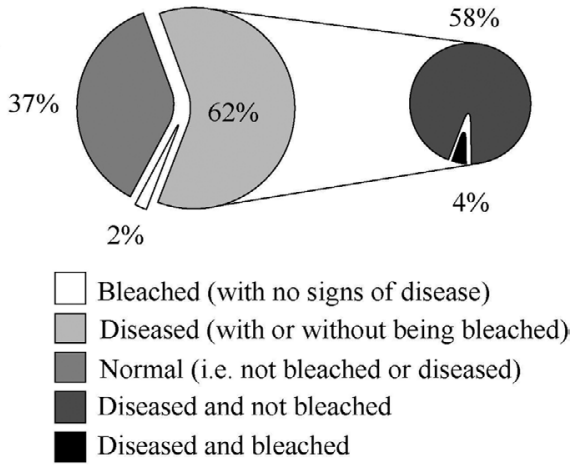

Fig. 5. Montipora aequituberculata. Percentage of colonies at (a) Bright Point, (b) Arthur Bay and (c) Florence Bay that were bleached (with no signs of disease), diseased (with or without being bleached) or normally pigmented (i.e. not bleached or diseased) during the surveys of early February 2002. The pie charts at right show the percentage of the diseased corals that were also considered bleached (i.e. in contrast to Bright Point, very few, $4 \%$, of the 'diseased' colonies at Florence Bay were also bleached) 


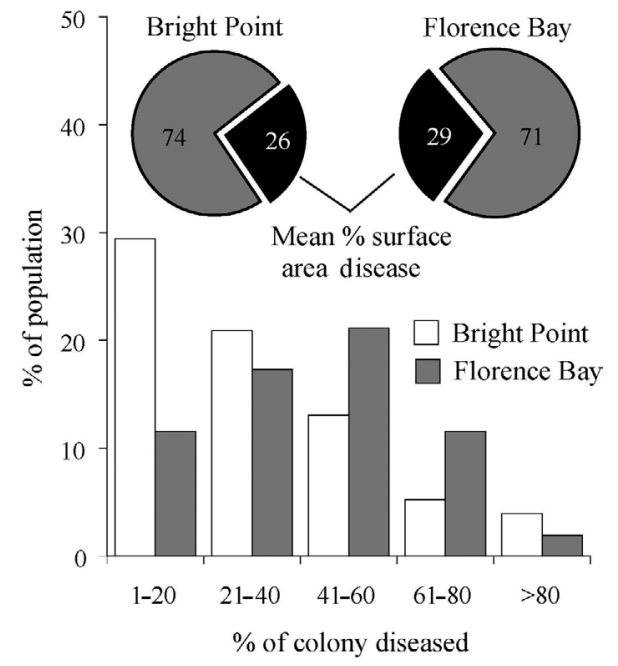

Fig. 6. Montipora aequituberculata. Size distribution of disease lesions in $M$. aequituberculata at Bright Point and Florence Bay showing the percentage of the population with a given percentage of surface area of the colony that is diseased (assessed by divers on 31 January 2002). Upper pie charts: mean percentage of the surface area of corals at Bright Point or Florence Bay that were diseased (black) or healthy (grey) on 31 January 2002

rence Bay (Fig. 4a,b), surveys were conducted to examine the relationship between bleaching and disease at both locations. At Bright Point, $72.5 \pm 5.1 \%$ (SD) of the colonies had disease lesions and of these, half were considered bleached and the other half considered normally-pigmented (Fig. 5a). At Florence Bay, $61.5 \pm 13.5 \%(\mathrm{SD})$ of the colonies had disease lesions and only $4 \%$ of these were both diseased and bleached (Fig. 5c); thus the majority of diseased corals had normal pigmentation. At both Bright Point and Florence Bay, the mean percentage surface area of the corals that was affected was $\sim 30 \%$; however, at Bright Point, the disease was mostly present as small patches $(<20 \%$ of the coral surface area), whilst at Florence Bay, most instances of disease covered 41 to $60 \%$ of the colony surface (Fig. 6).
Further underwater surveys conducted in early February 2002 revealed blackened diseased lesions on a number of other coral species including Acropora latistella, A. subulata, Echinopora lamellosa, Fungia spp., Merulina ampliata and Turbinaria mesenterina. For A. latistella and A. subulata, divers estimate that $\sim 5 \%$ of the corals examined had atramentous patches, whilst for T. mesenterina, $\sim 1 \%$ of the coral appeared diseased. Blackened 'diseased' lesions were also observed on Montipora aequituberculata at other sites around Magnetic Island, including Middle Reef and Picnic Bay Reef (Fig. 1), although the incidence of disease was not quantified.

\section{Microbial analyses}

A qualitative in situ analysis of the microbial community present in normal and diseased coral tissue, and adjacent sediment was carried out using fluorescence in situ hybridisation (FISH). Autofluorescence from the coral tissue was mostly avoided by exciting with light in the red and far red wavelengths. No bacteria were observed within disease-free sections of the coral, and symbiotic dinoflagellate algae appeared to be the only microorganisms present within these tissues (Table 1). A diverse assemblage of microorganisms was identified in sections of white diseased coral tissue (Table 1). Alphaproteobacteria, Gammaproteobacteria, and Cytophaga/Flavobacterium group of Bacteroidetes were present in diseased sections according to FISH. Although a quantitative analysis was not performed, clusters of Alphaproteobacteria were the most abundant microorganisms. Betaproteobacteria were only observed on a single occasion and in low numbers in the diseased coral tissue. Areas of blackened tissue revealed an abundance of short filamentous bacteria, which bound both ALF1b (for Alphaproteobacteria) and GAM42a (for Gammaproteobacteria).

A total of 73 bacterial 16S rDNA clones were obtained from a diseased coral specimen from Geof-

Table 2. Proportions of major bacterial divisions of the clone library from a specimen of diseased Montipora aequituberculata. OTU: operational taxonomic units

\begin{tabular}{|lccc|}
\hline Bacterial division & $\begin{array}{c}\text { Number of } \\
\text { OTUs }\end{array}$ & $\begin{array}{c}\text { Number and \% } \\
\text { of clones in clone library }\end{array}$ & $\begin{array}{c}\text { Number of clones } \\
\text { sequenced and analysed }\end{array}$ \\
\hline Cytophaga-Flavobacterium of Bacteroidetes & 5 & $10(14 \%)$ & One clone from each OTU \\
Firmicutes & 6 & $14(19 \%)$ & One clone from each OTU \\
Alphaproteobacteria & 5 & $42(57 \%)$ & One clone from each OTU \\
Betaproteobacteria & 1 & $2(3 \%)$ & One clone from the OTU \\
Gammaproteobacteria & 2 & $3(4 \%)$ & Both clones \\
Deltaproteobacteria & 1 & $2(3 \%)$ & One clone from the OTU \\
\hline
\end{tabular}



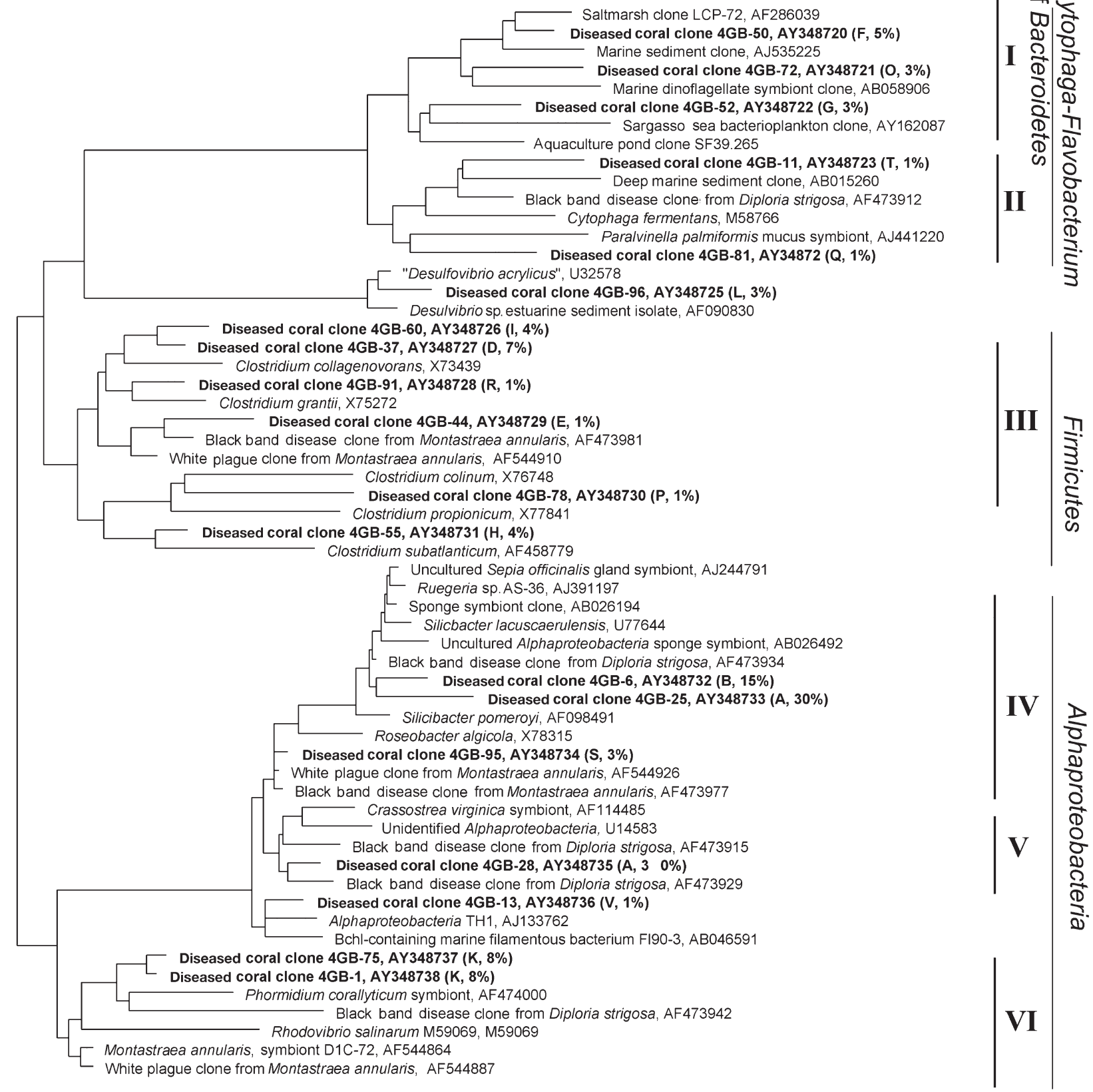

Fig. 7. Evolutionary-distance dendogram of clones from this study and their closest phylogenetic relatives based on phylogenetic analyses of 16S rDNA data. For reference sequences, 1366 nucleotides are compared following the use of the Lane mask (Lane 1991). Clone sequences from the current study were shorter and were added by the ARB parsimony insertion tool. These are presented in bold, followed by, in parenthesis, the clone operational taxonomnic unit (OTU) (A, B, D, E, F, G, H, I, K, L, O, P, Q, R, S, $\mathrm{T}, \mathrm{V}$ ) and percentage occurrence of that OTU in the clone library. Major phylogenetic groups (Cytophaga-Flavobacterium of Bacteroidetes; Firmicutes and Alphaproteobacteria) and clone groupings are illustrated by bars on the right. The bar represents $10 \%$ estimated sequence divergence. Outgroup (not shown) was Pseudomonas cellulosa (AF452103)

frey Bay. Evaluation of the clone library by RFLP identified 20 different operational taxonomic units (OTUs). Clone inserts from OTU representatives were partially DNA sequenced and the bacterial groups that were identified are summarised in Table 2. According to BLAST, the 16S rDNA sequences came from 6 different phyla or subphyla: Firmicutes, Cytophaga/ Flavobacterium of Bacteroidetes, Alphaproteobacteria, 
Betaproteobacteria, Gammaproteobacteria and Deltaproteobacteria. The $16 \mathrm{~S}$ rDNA clones predominantly came from Alphaproteobacteria (57\%) and Firmicutes (19\%), specifically from the genus Clostridium (Fig. 7). The 16S rDNA sequences obtained in this study were mostly phylogenetically affiliated with bacterial 16S rDNA sequences obtained from other studies of black band diseased Montastraea annularis and Diploria strigosa (17), and plague-like disease from $M$. annularis (Pantos et al. 2003) (Fig. 7). Specific groups that were highly represented by coral disease $16 \mathrm{~S}$ rDNA sequences could be identified within the Alphaproteobacteria, Firmicutes and Cytophaga/Flavobacterium of Bacteroidetes.

Members of the Alphaproteobacteria division dominated the clone library in this study and were divided into 3 major groups consisting of coral disease sequences (Groups IV, V and VI in Fig. 7). Two of the Alphaproteobacteria OTUs in this study, designated OTU A (represented by Clones 4GB-25 and 4GB-28 in Fig. 7) and OTU B (represented by Clone 4GB-6 in Fig. 7) comprised $45 \%$ of all clones. Clones $4 \mathrm{~GB}-25$ and 4GB-6 (Group IV in Fig. 7) clustered with Ruegeria and Silicibacter species. Group V in the Alphaproteobacteria consisted of clone 4GB-28 from this study and bacterial 16S rRNA gene sequences from black band diseased Diploria strigosa and a Crassostrea virginica pathogen (Accession number AF114485). Group VI contained 2 closely related sequences from this study, 4GB-1 and 4GB-75 (OTU K, Fig. 7), a black band disease clone from Diploria strigosa (Accession number AF473942) and an uncultured Alphaproteobacteria grown in a culture of Phormidium corallyticum (Cooney et al. 2002). This group of sequences also clustered together with a naturally occurring symbiont of $M$. annularis and $16 \mathrm{~S}$ rRNA gene sequences found in plague-like diseased corals. The majority of Alphaproteobacteria and several Cytophaga/Flavobacterium 16S rRNA gene sequences of clones from diseased corals clustered with sequences from symbionts of marine algae and invertebrates. Groups I and II in the Cytophaga/ Flavobacterium and Group III in Clostridium also contained sequences of the various coral disease studies (Fig. 7). Approximately 18\% of clones from our clone library contained inserts from Clostridium (Firmicutes). The Gammaproteobacteria sequences (not shown in Fig. 7) found in this study were not affiliated with any sequences obtained in other diseased coral studies.

\section{DISCUSSION}

A coral disease outbreak occurred on the fringing reefs of a continental island of the Great Barrier Reef
(Australia) during the height of the 2001/2002 (austral) summer. The disease was characterised by rapidly spreading patches of blackened, dead tissues (lesions). In the absence of reported diseases or syndromes presenting the same or similar symptoms, we have used the term 'atramentous necrosis' to describe the putative disease state. Although documented closely in one species, Montipora aequituberculata, small atramentous patches were noted on 5 other coral species from 3 separate families. In plate-like Acropora latistella and A. subulata, an incidence rate of slightly less than $5 \%$ was estimated in semi-quantitative surveys. Whilst present on all reefs around Magnetic Island, the areal extent of the disease on the Great Barrier Reef is unknown.

The atramentous lesions spread over the Montipora aequituberculata colonies at rates of centimetres rather than millimetres per day, coalesced with neighbouring lesions and in a few instances, resulted in colonies up to $1 \mathrm{~m}$ across dying in less than $2 \mathrm{wk}$. The spread of the disease through the population was equally dramatic, with the number of colonies with diseased (atramentous) lesions doubling each week to eventually include $75 \%$ of the study population. Equally remarkable was the abrupt end to the epizootic, where lesions ceased spreading and became buried in a layer of sediment and algae. This effectively masked all signs of the outbreak. Fresh lesions were infrequently observed after mid-February 2001 and hence, the epizootic was effectively over in a calendar month. The rapid and transient nature of disease outbreaks has been noted before (Hayes \& Goreau 1998), but the rapidity and severity of an outbreak has not been described previously.

\section{In situ studies}

Temperature appeared to be a key variable associated with the outbreak. Diseased lesions first appeared during the summer of 2001/2002, disappeared during the winter and then reappeared the next summer. Similar patterns have been reported in black band disease in the Caribbean and the Florida Keys (Rützler et al. 1983, Edmunds 1991, Kuta \& Richardson 1996, Bruckner \& Bruckner 1997), yellow band disease on Acropora clathrata in the Arabian Gulf (Korrûbel 1998), white pox disease on A. palmata in the Florida Keys (Patterson et al. 2002), white plague on corals in Puerto Rico (Bruckner \& Bruckner 1997) and also in bacterial bleaching in Oculina patagonica (Kushmaro et al. 1998). In a recent review of the ecology and aetiology of newly emerging marine diseases, Porter et al. (2001) emphasise the repeated theme of a link between coral disease and temperature; although seasonality is not clear in all cases (Santavy et al. 2001). 
The epizootic occurred over a period in which many of the corals at Magnetic Island were undergoing bleaching. Bleaching events are also associated with elevated seawater temperatures and are regular occurrences at Magnetic Island. They have now been recorded on 7 occasions since 1979 (Jones et al. 1997, Berkelmans \& Oliver 1999) and in situ temperature records are available for 4 of these events. A clear relationship between elevated temperature and bleaching has been established (Jones et al. 1997, Berkelmans \& Oliver 1999). Why the corals bleached when they did is not surprising given the thermal regimes. For example, seawater temperatures at Bright Point in early January 2002 were amongst the highest in a decade long record of in situ temperatures (Jones et al. 1997, Berkelmans \& Oliver 1999, Berkelmans 2002) and bleached corals were observed soon afterwards. The site furthest from the mainland (Florence Bay) did not experience this initial bout of warmer water and the corals only bleached after a second period of warmer temperatures in early February 2002. Thus bleaching was staggered by about 1 mo between Bright Point and Florence Bay, and the timing, extent and severity of the bleaching is entirely consistent with the thermal regime.

In contrast to the 'asynchronous' pattern of bleaching between sites, atramentous lesions were common at both Bright Point and Florence Bay in January 2002. This is significant as it means that the rapid increase in partial mortality recorded at Florence Bay in January 2002 (Fig. 6c) could only be attributed to the disease and not to the bleaching. A similar pattern of mortality occurred over the same period at Bright Point, where many of the corals were bleached and diseased. In situ observations indicated that most partial mortality on bleached colonies was associated with the diseased lesions (cf. Fig. 3c,e) and on these lines of evidence, we attribute virtually all mortality observed in Montipora aequituberculata over the early summer to the disease. Clearly without the frequent (weekly and twice weekly) monitoring of individual coral colonies over the summer period, the outbreak may well have gone unnoticed. Any postbleaching surveys attempting to quantify the extent of the bleaching event, would almost certainly have attributed the mortality in $M$. aequituberculata to the bleaching event rather than an epizootic.

Given the seasonality associated with atramentous necrosis and the co-occurrence of the epizootic with unusually warm seawater temperatures around Magnetic Island, it is unusual that the corals at Florence Bay (that experienced the slightly cooler seawater temperatures than Bright Point) were as affected by the disease. However, diseased corals were identified first at Arthur and Florence Bay a few weeks before Bright
Point, and the pattern may simply reflect a longer developmental time. This is supported by the size distribution of the lesions, where at Florence Bay they were more developed (covered a larger surface area). Overall, the pattern is consistent with the spread of a pathogen(s) into Cleveland Bay, following the prevailing currents (Larcombe et al. 1995). A similar spreading pattern of a coral disease (black band disease) across a Jamaican reef system, following the direction of the predominant current, has been described previously (Bruckner \& Bruckner 1997).

Based on the long-term record, the highly variable seawater temperature experienced at Florence Bay in January 2002 was a rare event (R. J. Jones unpubl. data). What caused this variability is unknown, but the sites furthest from the mainland were probably exposed to a pool of cooler sea water that became tidallymixed into the warmer waters of Cleveland Bay. Since the epizootic occurred in a 3 wk period coincident with this period of variable seawater temperature, it is debatable whether there was a causal link between the two. The pronounced diel variability in water temperature over this period may have been a significant external stress to the corals, alternatively the cool pool of seawater might also have been the source of (a) primary or secondary pathogen(s) that became virulent when mixed into warmer surface waters of Cleveland Bay. This explanation cannot account for the appearance of lesions before January 2002 and also during the following summer, although at these stages, the lesions were usually small (1 to $2 \mathrm{~cm}$ across) and the expansive patches of atramentous tissue that occurred in January 2002 were not observed.

\section{Microbial analysis}

The 16S rDNA sequences of material sourced from diseased Montipora aequituberculata tissues indicate the presence of mostly marine bacteria, including those found in black band disease (BBD) infected Montastraea annularis (Cooney et al. 2002), Diploria strigosa (Frias-Lopez et al. 2002) and white plague disease-infected $M$. annularis (Cooney et al. 2002). Members of the Alphaproteobacteria, Gammaproteobacteria, Firmicutes and Cytophaga/Flavobacterium of Bacteroidetes appear to be the abundant microorganisms in coral reef systems and specifically in coral microbial studies (this study, Cooney et al. 2002, Rohwer et al. 2002, Rosenberg \& Ben-Haim 2002, Pantos et al. 2003). In particular, the $16 \mathrm{~S}$ rDNA sequences from the above mentioned coral disease studies form definitive groups within the Alphaproteobacteria, Firmicutes and Cytophaga/Flavobacterium of Bacteroidetes (Fig. 7). It could be that a specific complex micro- 
bial community is responsible for the coral disease, or this microbial community could comprise secondary invaders of diseased tissue. The oral cavity and gastrointestinal tract of mammals are sites where complex microbial communities are thought responsible for disease states like gingivitis (Ashimoto et al. 1996) and inflammatory bowel diseases (Seksik et al. 2003).

Corals suffering from atramentous necrosis and BBD share the same striking black pigmentation, prompting us to consider the possible similarities. The microbial biofilm in BBD is dominated by the cyanobacterium Phormidium corallyticum, Beggiatoa spp. and Desulfovibrio spp. (Richardson 1997). Mortality in BBD is also thought to occur from the sulphide and anoxic conditions produced by the microbial biofilm (Carlton \& Richardson 1995). In our study, no cyanobacteria were observed in the FISH samples and no cyanobacterial sequences obtained in the clone library. We found a dominance of short filamentous ALF1b- and GAM42a-binding bacteria and many Alphaproteobacteria sequences in the clone library from the black tissue of Montipora aequituberculata. An Alphaproteobacteria normally found in axenic cultures of $P$. corallyticum clustered with sequences from our study, and also from studies of BBD-infected Diploria strigosa and white plague infected and healthy Montastrea annularis (Group VI of Alphaproteobacteria, Fig. 7). One 16S rDNA clone sequence from our study was closely related to Desulfovibrio acrylicus (an anaerobic marine bacterium); however, these sequences were not phylogenetically associated with the Desulfovibrio sequences consistently obtained in all the specimens of BBD infected corals reported by Cooney et al. (2002). Our study identified sequences clustering with both $D$. acrylicus and Clostridium propionicum, which are known for their strong sulphate reducing capabilities especially in marine environments (Van der Maarel et al. 1996). The presence of sulphur was not verified in atramentous necrosis of $M$. aequituberculata; however, the strong sulphur smell and the presence of sulphate reducing organisms in the diseased coral suggests sulphur presence, which could have also contributed to coral death.

Recently, Rohwer et al. (2001, 2002) suggested the possibility of specific symbiotic dinoflagellate-coralmicrobe associations including one between Montastraea franksi and the Alphaproteobacteria, Silicibacter lacuscaerulensis. The dominant OTU identified in our study did in fact cluster with $S$. lacuscaerulensis and with previously reported 16S rRNA gene sequences from BBD infected coral tissue (Group VI Alphaproteobacteria) (Cooney et al. 2002, Frias-Lopez et al. 2002). Perhaps these Alphaproteobacteria co-exist with the coral, but become opportunistic pathogens when the symbiosis is disturbed by environmental con- ditions, such as elevated temperature. According to FISH, bacteria were not observed in the upper layers of healthy coral tissue, but the black material on Montipora aequituberculata was dominated by short filamentous bacteria binding both ALF1b (for Alphaproteobacteria) and GAM42a (for Gammaproteobacteria). This apparent probing anomaly could be due to problems with either ALF1b or GAM42a. ALF1b is known to be highly unspecific for Alphaproteobacteria (Loy et al. 2002) and GAM42a binding inconsistencies have previously been reported (Buchholz-Cleven et al. 1997, Yeates et al. 2003). Full length insert sequencing of the Alphaproteobacteria and Gammaproteobacteria 16S rDNA clones obtained in our library will facilitate the design of specific probes to determine the identity and abundance of coral-associated Alphaproteobacteria or Gammaproteobacteria, and to clarify their in situ spatial arrangements and global distribution.

Group V in Alphaproteobacteria included 4GB-28 from diseased Montipora aequituberculata, sequences from BBD diseased Diploria strigosa (Cooney et al. 2002) and the putative aetiological agent of juvenile oyster disease (JOD) of Crassostrea virginica (Boettcher et al. 1999, 2000). Peak infection of oysters C. virginica occurs in the summer months (Boettcher et al. 1999, 2000) and there is a clear summer seasonal association in both BBD and atramentous necrosis (see above).

The physical appearance and progression of disease in white plague infections is markedly different from that of BBD and the disease described here. However, we found many similar $16 \mathrm{~S}$ rDNA sequences from white plague infected Montastraea annularis clustering with 16S rDNA sequences from black band infected Diploria strigosa and M. annularis from the Caribbean, and atramentous necrosis infected Montipora aequituberculata. This suggests that there are common aetiological agents associated with the diseases, or that a bacterial community develops that is specific to degrading coral tissues. Nevertheless, this discovery strongly supports the fabrication of a broad diagnostic coral microarray, 'phylochip', targeting these specific coral disease associated microorganisms.

\section{Sea temperature, coral disease and coral bleaching}

Understanding the links between temperature, coral disease and coral bleaching will become increasingly important in light of projected changes in sea temperature. Temperature can increase pathogen development, survival and transmission rates as well as increase host susceptibility (Harvell et al. 2002). There is evidence of temperature-dependent growth rates in 
Vibrio shiloi AK-1, the pathogen that causes bacterial bleaching in Oculina patagonica (Kushmaro et al. 1998), and Aspergillus sydowii, the fungal pathogen causing aspergillosis in gorgonians (Alker et al. 2001). There is also evidence of temperature affecting host susceptibility. Recently, Harvell et al. (2001) have indicated that mortality in bleached gorgonians Briareum asbestinum in the Florida Keys was caused by a disease rather than the bleaching stress itself. That is, loss of algal symbionts (i.e. bleaching) weakened the host, thereby increasing susceptibility. Effectively, this is more of an 'indirect' effect of thermal stress on host susceptibility, mediated through the coral bleaching response. In this study, the disease outbreak occurred simultaneously with the bleaching of corals at one site, but preceded the bleaching of the corals by several weeks at the other site. Hence, in this instance, temperature may have had more direct effects on host susceptibility (and pathogen development).

It is unclear if the high disease rates in corals generally reflect their unusual vulnerability to disease or whether other coral reef organisms are similarly affected (Harvell et al. 2001). However, the bleaching response of corals is a highly unusual and taxonspecific response that may predispose them to disease infestation. For example, water temperatures may only differ slightly (i.e. sometimes $<1^{\circ} \mathrm{C}$ ) between 'bleaching' and 'non-bleaching' years (Hoegh-Guldberg 1999), with profoundly relevant physiological and ecological consequences (Douglas 2003). Bleached corals are in a weakened (susceptible) state for a considerable period (i.e. weeks or months: Jones \& Yellowlees 1997, Edmunds et al. 2003), despite the actual thermal stress occurring over much shorter periods. Thus, the legacy of a short term thermal stress is endured for a considerable time and hence, bleaching may thus serve not only to mediate but also to amplify the effect of temperature stress. Whilst recognising that synergisms rather than single factors are likely to be contributing to the increased incidence in diseases of corals in recent years, we speculate as to whether it is the indirect effects of temperature mediated by the coral bleaching response that is more significant than the direct effects per se. Hence, perhaps the 'unusual vulnerability' of corals to disease infestation may be the result of the unusual predilection of the symbiosis to dissociate during thermal stress.

In summary, the events occurring at Magnetic Island over the summer of 2001/2002 were unusual compared with other reports of coral disease. We have shown that high levels of mortality of corals following an anomalously warm summer were not caused by bleaching per se but by coincident increase in the presence of an epizootic. The disease was present during the summer rather than winter months, but the level of the re- sponse cannot be reconciled in terms of a seasonal pattern, suggesting a new phenomenon. Rapid, ephemeral and catastrophic disease outbreaks, with the potential for wide-scale partial colony mortality may represent a new challenge to corals in the summer months and to corals in light of predicted increases in seawater temperature from climate change.

Acknowledgements. P. C. Burrell is gratefully acknowledged for extensive help with phylogenetic analysis. J. Davidson, C. Ryan, S. Neale and N. Taylor are thanked for their assistance in the field. This project was supported by ARC Linkage grant no. LP0453609 and the Great Barrier Reef Marine Park Authority, The Great Barrier Reef Research Foundation, Douglas Shire Council and $\mathrm{P} \& \mathrm{O}$ resorts (Australia).

\section{LITERATURE CITED}

Alker AP, Smith GW, Kim K (2001) Characterization of Aspergillus sydowii (Thom et Church), a fungal pathogen of Caribbean sea fan corals. Hydrobiologia 460:105-111

Altschul SF, Gish W, Miller W, Myers EW, Lipman DJ (1990) Basic local alignment search tool. J Mol Biol 215:403-410

Amann RI, Binder BJ, Olson RJ, Chisholm SW, Devereux R, Stahl DA (1990) Combination of 16S rRNA-targeted oligonucleotide probes with flow cytometry for analyzing mixed microbial populations. Appl Environ Microbiol 56: 1919-1925

Amann RI, Ludwig W, Schleifer KH (1995) Phylogenetic identification and in situ detection of individual microbial cells without cultivation. Microbiol Rev 59:143-169

Antonius A (1973) New observations on coral destruction in reefs. Tenth Meeting of the Association of Island Marine Laboratories of the Caribbean (Abstracts). University of Puerto Rico (Mayaguez) 10:3

Aronson RB, Precht WF, Macintyre IG (1998) Extrinsic control of species replacement on a Holocene reef in Belize: the role of coral disease. Coral Reefs 17:223-230

Ashimoto A, Chen C, Bakker I, Slots J (1996) Polymerase chain reaction detection of 8 putative periodontal pathogens in subgingival plaque of gingivitis and advanced periodontitis lesions. Oral Microbiol Immunol 11:266-273

Berkelmans R (2002) Time-integrated thermal bleaching thresholds of reefs and their variation on the Great Barrier Reef. Mar Ecol Prog Ser 229:73-82

Berkelmans R, Oliver JK (1999) Large-scale bleaching of corals on the Great Barrier Reef. Coral Reefs 18:55-60

Björnsson L, Hugenholtz P, Tyson GW, Blackall LL (2002) Filamentous Chloroflexi (green non-sulfur bacteria) are abundant in wastewater treatment processes with biological nutrient removal. Microbiology 148:2309-2318

Boettcher KJ, Barber BJ, Singer JT (1999) Use of antibacterial agents to elucidate the etiology of juvenile oyster disease (JOD) in Crassostrea virginica and numerical dominance of an alpha-proteobacterium in JOD affected animals. Appl Environ Microbiol 65:2534-2539

Boettcher KJ, Barber BJ, Singer JT (2000) Additional evidence that juvenile oyster disease is caused by a member of the Roseobacter group and colonization of nonaffected animals by Stappia stellulata like strains. Appl Environ Microbiol 66:3924-3930

Brown BE (1997) Coral bleaching: causes and consequences. Coral Reefs 16:129-138 
Bruckner AW (2002) Priorities for effective management of coral diseases. NOAA Tech Memo, NMFS-OPR-22. NOAA, Silver Spring, MD

Bruckner AW, Bruckner RJ (1997) Outbreak of coral disease in Puerto Rico. Coral Reefs 16:260

Buchholz-Cleven BEE, Rattunde B, Straub KL (1997) Screening for genetic diversity of isolates of anaerobic Fe(II)-oxidizing bacteria using DGGE and whole-cell hybridisation. System Appl Microbiol 20:301-309

Burrell PC, Keller J, Blackall LL (1998.) Microbiology of a nitrite-oxidizing bioreactor. Appl Environ Microbiol 64: 1878-1883

Bythell JC, Barer MR, Cooney RP, Guest JR, O'Donnell AG, Pantos O, Le Tissier MDA (2002) Histopathological methods for the investigation of microbial communities associated with disease lesions in reef corals. Lett Appl Microbiol 34:359-364

Carlton RG, Richardson LL (1995) Oxygen and sulfide dynamics in a horizontally migrating cyanobacterial mat: black band disease of corals. FEMS Microbiol Ecol 18:155-162

Cooney RP, Pantos O, Le Tissier MDA, Barer MR, O'Donnell AG, Bythell JC (2002) Characterization of the bacterial consortium associated with black band disease in coral using molecular microbiological techniques. Environ Microbiol 4:401-413

Daims H, Bruhl A, Amann R, Schleifer KH, Wagner M (1999) The domain-specific probe EUB338 is insufficient for the detection of all bacteria: development and evaluation of a more comprehensive probe set. Syst Appl Microbiol 22: $434-444$

Devereux R, Kane MD, Winfrey J, Stahl DA (1992) Genusspecific and groups specific hybridisation probes for determinative and environmental studies of sulfatereducing bacteria. Syst Appl Microbiol 15:601-609

Douglas AE (2003) Coral bleaching - how and why? Mar Pollut Bull 46:385-392

Dustan P (1977) Vitality of reef coral populations off Key Largo, Florida: recruitment and mortality. Environ Geol 2: $51-58$

Edmunds PJ (1991) Extent and effect of black band disease on a Caribbean reef. Coral Reefs 10:161-165

Edmunds PJ, Gates RD, Gleason DF (2003) The tissue composition of Montastraea franksi during a natural bleaching event in the Florida Keys. Coral Reefs 22:54-62

Fitt WK, Brown BE, Warner ME, Dunne RP (2001) Coral bleaching: interpretation of thermal tolerance limits and thermal thesholds in tropical corals. Coral Reefs 20:51-65

Frias-Lopez J, Zerkle AL, Bonheyo GT, Fouke BW (2002) Partitioning of bacterial communities between seawater and healthy, black band diseased, and dead coral surfaces. Appl Environ Microbiol 68:2214-2228

Gladfelter WB, Gladfelter EH, Monahan RK, Ogden JC, Dill RF (1977) Coral destruction. Environmental studies of Buck Island Reef National Monument. National Park Service, US Department of Interior, Biosphere Reserve Research Report No. 6. St. Croix, US Virgin Islands

Glynn PW (1996) Coral reef bleaching: facts, hypotheses and implications. Global Change Biol 2:495-509

Goreau TJ, Cervino J, Goreau M, Hayes R and 14 others (1998) Rapid spread of diseases in Caribbean coral reefs. Rev Biol Trop 46 (Suppl 5):157-171

Green EP, Bruckner AW (2000) The significance of coral disease epizootiology for coral reef conservation. Biol Conserv 96:347-361

Harvell CD, Kim K, Burkholder JM, Colwell RR and 9 others (1999) Emerging marine diseases-climate links and anthropogenic factors. Science 285:1505-1510
Harvell D, Kim K, Quirolo C, Weir J, Smith G (2001) Coral bleaching and disease: contributors to 1998 mass mortality in Briareum asbetinum (Octocorallia, Gorgonacea). Hydrobiologia 460:97-104

Harvell CD, Mitchell CE, Ward JR, Altizer S, Dobson AP, Ostfeld RS, Samuel MD (2002) Climate warming and disease risks for terrestrial and marine biota. Science 296: $2158-2162$

Hayes RL, Goreau NI (1998) The significance of emerging diseases in the tropical coral reef ecosystem. Rev Biol Trop 46 (Suppl 5):173-185

Hoegh-Guldberg O (1999) Climate change, coral bleaching and the future of the world's coral reefs. Mar Freshw Res 50:839-866

Hughes TP (1994) Catastrophes, phase shifts, and large scale degradation of a Caribbean coral reef. Science 265: $1547-1551$

Jones RJ, Yellowlees DY (1997) Algal (=zooxanthellae) regulation and control in hard corals. Philos Trans R Soc London B Biological Science 352:457-468

Jones RJ, Oliver JK, Berkelmans R (1997) The recurrent bleaching of corals at Magnetic Island (Australia) relative to air and seawater temperature. Mar Ecol Prog Ser 158: 289-292

Korrûbel JL (1998) A new coral disease from the southern Arabian Gulf. Coral Reefs 17:22

Kushmaro A, Rosenberg E, Fine M, Ben Haim Y, Loya Y (1998) Effect of temperature on bleaching of the coral Oculina patagonica by Vibrio AK-1. Mar Ecol Prog Ser 171:131-137

Kuta KG, Richardson LL (1996) Abundance and distribution of black band disease in coral reefs in the northern Florida Keys. Coral Reefs 15:219-223

Lane DJ (1991) 16S/23S rRNA sequencing. In: Stackebrandt E, Goodfellow M (ed) Nucleic acid techniques in bacterial systematics. Academic Press, Chichester, p 115-175

Larcombe P, Ridd PV, Prytz A, Wilson B (1995) Factors controlling suspended sediment on inner-shelf coral reefs, Townsville, Australia. Coral Reefs 14:163-171

Loy A, Daims H, Wagner M (2002) Activated sludge: molecular techniques for determining community composition. In: Bitton G (ed) The encyclopedia of environmental microbiology. Wiley, New York, p 26-43

Loya Y, Sakai K, Yamazato K, Nakano Y, Sambali H, van Woesik R (2001) Coral bleaching: the winners and the losers. Ecol Lett 4:122-131

Manz WR, Amann W, Ludwig M, Wagner, Schleifer KH (1992) Phylogenetic oligodeoxynucleotide probes for the major subclasses of proteobacteria-problems and solutions. Syst Appl Microbiol 15:593-560

Manz W, Amann R, Ludwig W, Wagner M, Schleifer KH (1996) Application of a suite of 16S rRNA-specific oligonucelotide probes designed to investigate bacteria of the phylum cytophage-flavobacter-bacteroides in the natural environment. Microbiology 142:1097-1106

Pantos O, Cooney RP, Le Tissier MDA, Barer MR, O'Donnell AG, Bythell JC (2003) The bacterial ecology of a plaguelike disease affecting the Caribbean coral Montastrea annularis. Environ Microbiol 5:370-382

Patterson KL, Porter JW, Ritchie KB, Polson SW, Mueller E, Peters EC, Santavy DL, Smith GW (2002) The etiology of white pox, a lethal disease of the Caribbean elkhorn coral, Acropora palmata. Proc Natl Acad Sci USA 99:8725-8730

Peters EC (1997) Diseases of coral reef organisms. In: Birkeland C (ed) Life and death of coral reefs. Chapman \& Hall, New York, p 114-139

Porter JW, Dustan P, Jaap WC, Patterson KL, Kosmynin V, 
Meier OW, Patterson ME, Parsons M (2001) Patterns of spread of coral disease in the Florida Keys. Hydrobiologia 460:1-24

Reeves L (1994) Newly discovered: yellow band disease strikes Keys reefs. Underwater USA 11:16

Richardson LL (1997) Occurrence of the black band disease cyanobacterium on the healthy corals of the Florida Keys. Bull Mar Sci 61:485-490

Richardson LL (1998) Coral diseases: what is really known? Trends Ecol Evol 13:438-443

Ritchie KB, Smith GW (1998) Type II white-band disease. Rev Biol Trop 46 (Suppl 5):199-203

Ritchie KB, Polson SW, Smith GW (2001) Microbial disease causation in marine invertebrates: problems, practices, and future prospects. Hydrobiologia 460:131-139

Rohwer F, Breitbart M, Jara J, Azam F, Knowlton N (2001) Diversity of bacteria associated with the Caribbean coral Montastraea franksi. Coral Reefs 20:85-91

Rohwer F, Seguritan V, Azam F, Knowlton N (2002) Diversity and distribution of coral-associated bacteria. Mar Ecol Prog Ser 243:1-10

Rosenberg E, Ben-Haim Y (2002) Microbial diseases of corals and global warming. Environ Microbiol 4:318-326

Editorial responsibility: Otto Kinne (Editor), Oldendorf/Luhe, Germany
Rützler K, Santavy DL, Antonius A (1983) The black band disease of Atlantic reef corals. PSZN I: Mar Ecol 4:329-358

Santavy DL, Peters EC (1997) Microbial pests: Coral disease in the Western Atlantic. In: Macintyre IG (ed) Proc 8th Int Coral Reef Symp. Smithsonian Tropical Research Institute, Balboa, Panama, p 607-612

Santavy DL, Mueller E, Peters EC, MacLaughlin L, Porter JW, Patterson KL, Campbell J (2001) Quantitative assessment of coral diseases in the Florida Keys: strategy and methodology. Hydrobiologia 460:39-51

Seksik P, Rigottier-Gois L, Gramet G, Sutren M, Pochart P, Marteau R, Jian R, Dore J (2003) Alterations of the dominant faecal bacterial groups in patients with Crohn's disease of the colon. Gut 52:237-242

Van der Maarel MJEC, Aukema W, Hansen TA (1996) Purification and characterisation of a dimethylsulfoniopropionate cleaving enzyme from Desulfovibrio acrylicus. FEMS Microbiol Lett 143:241-245

Yeates C, Saunders AM, Crocetti GR, Blackall LL (2003) Limitations of the widely used GAM42a and BET42a probes targeting bacteria in the Gammaproteobacteria radiation. Microbiology 149:1239-1247

Zorpette G (1995) More coral trouble. Sci Am 273:36-37

Submitted: November 21, 2003; Accepted: June 17, 2004 Proofs received from author(s): October 19, 2004 